\title{
A new species of Hyphessobrycon (Teleostei: Characidae) from the upper rio Tocantins drainage, with bony hooks on fins
}

\author{
Vinicius A. Bertaco* and Luiz R. Malabarba****
}

\begin{abstract}
A new species of characid, Hyphessobrycon hamatus, is described from the upper rio Tocantins, Goiás, Brazil. The new species is distinguished from all other Hyphessobrycon species by the presence of bony hooks on dorsal, anal, pelvic, and pectoral fins of males, the two black humeral spots, the 4 or 5 teeth in the inner series of the premaxilla, a maxilla with 2-3 teeth, the iiiv, 16-18 anal-fin rays, and a lateral line with 10-32 perforated scales and 33-35 scales in a longitudinal series.

Uma nova espécie de caracídeo, Hyphessobrycon hamatus é descrita para os tributários do alto rio Tocantins, Goiás, Brasil. A nova espécie distingue-se das demais espécies de Hyphessobrycon pela presença de ganchos nos raios das nadadeiras dorsal, anal, pélvica e peitoral dos machos, duas manchas umerais pretas verticalmente alongadas, 4-5 dentes na série interna do pré-maxilar, 2-3 dentes no maxilar, 16-18 raios ramificados na nadadeira anal, 10-32 escamas perfuradas na linha lateral, e 3335 escamas em uma série longitudinal.
\end{abstract}

Key words: Neotropical, Hyphessobrycon balbus, taxonomy, systematics.

\section{Introduction}

Hyphessobrycon is a speciose genus of the family Characidae including more than 100 valid species (Lima et al., 2003; Lima \& Moreira, 2003; Lucena, 2003) distributed from southern Mexico to the río de La Plata in Argentina. The genus was proposed by Durbin in Eigenmann (1908:100) as a subgenus of Hemigrammus Gill, differing from the later by the absence of scales on the caudal-fin. Hyphessobrycon was extensively revised by Eigenmann $(1918,1921)$ whose accounts still constitute the single comprehensive review of the then known members of the genus. Publications on Hyphessobrycon subsequent to Eigenmann's revision usually involve only the description of new species occurring in restricted geographic areas of South and Central America. The recognition of groups of species in the genus is based primarily on similarities of color patterns (e.g. Géry, 1961; Géry, 1966; Géry, 1977). Weitzman \& Palmer (1997) recently hypothesized the existence of a monophyletic group of Hyphessobrycon species, based on the coloration pattern and the shape of the dorsal and anal fins of males that they termed the rosy tetra clade. Those authors did not, however, present a hypothesis for the resolution of the relationships of the remaining species in the genus. We herein describe a new species of Hyphessobrycon from the upper rio Tocantins basin.

\section{Methods and Materials}

Counts were taken as described by Fink \& Weitzman (1974) with the exception of the number of scale rows below lateral line that were counted from the scale row ventral of the lateral line to the scale row closest to the first pelvic-fin ray. Vertebral counts, supraneurals, gill-rakers, teeth and procurrent caudal-fin-ray counts were taken from cleared and stained specimens (c\&s) prepared according to the method of Taylor \& Van Dyke (1985). Vertebral counts include the four vertebra integrated in the Weberian apparatus with the terminal centrum counted as one vertebra. Teeth and bone SEM (scanning electronic microscope) photos were taken from dissected cleared and stained specimens.

All measurements other than SL are expressed as a percentage of SL except subunits of the head that are recorded as a percentage of head length (HL). Statistical tests of differences between the sexes were performed, but no differences were found.

\footnotetext{
* Laboratório de Ictiologia, Museu de Ciências e Tecnologia, Pontifícia Universidade Católica do Rio Grande do Sul, Av. Ipiranga 6681, 90619-900 Porto Alegre, RS, Brazil. e-mail: ubertaco@pucrs.br

** Departamento de Zoologia, IB, Universidade Federal do Rio Grande do Sul, Av. Bento Gonçalves, 9500, 91501-970 Porto Alegre, RS, Brazil.e-mail: malabarb@pucrs.br
} 


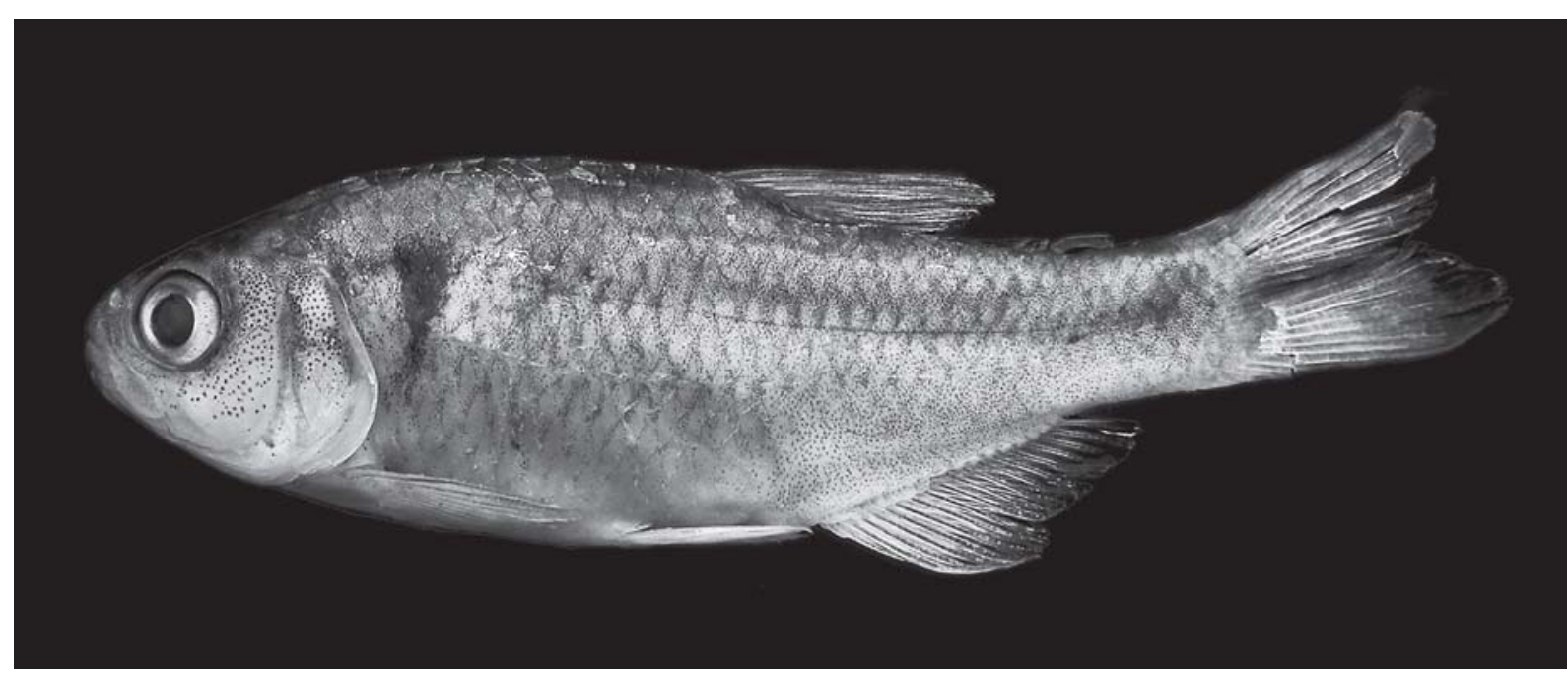

Fig. 1. Hyphessobrycon hamatus, MCP 34000, holotype, male, $43.1 \mathrm{~mm}$ SL; Brazil, Goiás, Mambaí, córrego Cana Brava, tributary of rio Vermelho.

The specimens examined are deposited in the Museu de Ciências e Tecnologia, Pontifícia Universidade Católica do Rio Grande do Sul, Porto Alegre (MCP), Museu de Zoologia, Universidade de São Paulo (MZUSP), and California Academy of Sciences, San Francisco (CAS).

\section{Hyphessobrycon hamatus, new species}

Figs. 1-2

Holotype. MCP 34000, 43.1 mm SL, male; Brazil, Goiás, Mambaí, córrego Cana Brava, tributary of rio Vermelho, rio Tocantins drainage, 14²9'S 466'W, 17 Dec 2002, Centro de Biologia Aquática - Universidade Católica de Goiás (UCG).

Paratypes. Brazil, Goiás, Mambaí: MCP 33930, 10 (6 males, 1 c\&s male, 3 females), 26.7-44.8 mm SL, 8 Sep 2002, MCP 33931, 6 (2 males; 1 male c\&s; 3 females), 32.0-39.9 mm SL, same locality as holotype. MCP 33929, 11 (5 males; 6 females), 29.040.1 mm SL, MZUSP 84411, 6 (2 males, 4 females), 29.4-36.6 mm SL, córrego Jataí, 14²9'S 466'W, 8 Sep 2002, Centro de Biologia Aquática, UCG.

Diagnosis. Hyphessobrycon hamatus is distinguished from all species of the genus, except $H$. socolofi Weitzman and $H$. erythrostigma (Fowler), by the presence of small bony hooks on the dorsal, anal, pelvic, and pectoral fins of males. The new species differs from $H$. socolofi and $H$. erythrostigma in the lower number of anal-fin rays (iii-v, 16-18, $\bar{x}=17, \mathrm{n}=28$ ) versus (iv, 28-30 and iv, 27-29, respectively), and by the absence of a black spot on dorsal fin versus the presence of such pigmentation.

Description. Morphometric data for Hyphessobrycon hamatus are summarized in Table 1. Body compressed and moderately deep; greatest body depth anterior to dorsal-fin origin. Dorsal body profile convex from nostril to dorsal-fin origin; posteroventrally slanted at dorsal-fin base; straight from last dorsal-fin ray to adipose-fin origin. Ventral profile of head convex. Ventral body profile convex from pectoral-fin origin to anal-fin origin. Body profile along anal-fin base straight and posterodorsally slanted. Caudal peduncle elongate, nearly straight to slightly concave along both dorsal and ventral margins.

Snout convex from margin of upper lip to vertical through anterior nostrils, straight from that point to tip of supraoccipital spine. Head small. Mouth terminal. Maxilla extending anteriorly to under middle of orbit, slightly curved, and aligned at approximately 45 degrees angle relative to longitudinal axis of body. Anterodorsal border of maxilla concave, posterodorsal border slightly convex, anteroventral border concave, and posteroventral border convex. Maxilla slightly widened posteriorly.

Premaxilla with two tooth rows; outer row with 3-4, rarely 5, tricuspid teeth with central cusp larger; inner row teeth 4-5, gradually decreasing in length from first to fourth teeth, last tooth considerably smaller with 3-5 cusps and central cusp longer and broader than other cusps. Two, rarely 3 maxillary teeth, with 3-5 cusps, central cusp slightly longer. Three or 4 anterior most dentary teeth larger, with 4-5 cusps, followed by medium sized tooth with 3-5 cusps, and 5-6 smaller teeth with 1-3 cusps or conical in shape; central cusp in all teeth two to three times longer and broader than remaining cusps. Cusp tips slightly curved posteriorly and towards inside of mouth.

Dorsal-fin rays ii, 9 (three specimens with ii, 8; $\mathrm{n}=28$ ); first unbranched ray approximately one-half length of second ray. Males with bony hooks in distal one-third of first to fifth branched rays. Dorsal-fin origin located posterior to middle of SL and posterior to vertical through pelvic-fin origin. Adipose-fin located approximately at vertical through insertion of last anal-fin ray.

Anal-fin rays iii-v, 16-18 $(\bar{x}=17, \mathrm{n}=28)$. First unbranched 
ray usually only apparent in cleared and stained specimens. Anal-fin profile slightly concave in females and males. Longest branched rays of depressed anal fin reaching origin of last anal-fin ray. Anal-fin origin located posterior to vertical through base of last dorsal-fin ray. Anal-fin rays of males bearing one pair of small, narrow, bony hooks along posterolateral border of each segment of lepidotrichia, usually along last unbranched two rays and ten anterior branched rays; hooks more numerous along second through fifth branched rays, rarely present on eleventh ray. Hooks usually located along posterior most branch and distal 1/2 to 2/ 3 of each ray.

Pectoral-fin rays i, 9-12, rarely 10 or $13(\bar{x}=10.8, \mathrm{n}=28)$. Males with bony hooks on distal portion of unbranched and first to sixth branched rays. Pelvic-fin rays i, 6-7 (usually i, 7; $\mathrm{n}=28$ ). Pelvic-fin origin located anterior to vertical through dorsal-fin origin. Pelvic fin of males usually bearing 1 bony hook per segment of lepidotrichia along ventromedial border of first to fifth branched rays.

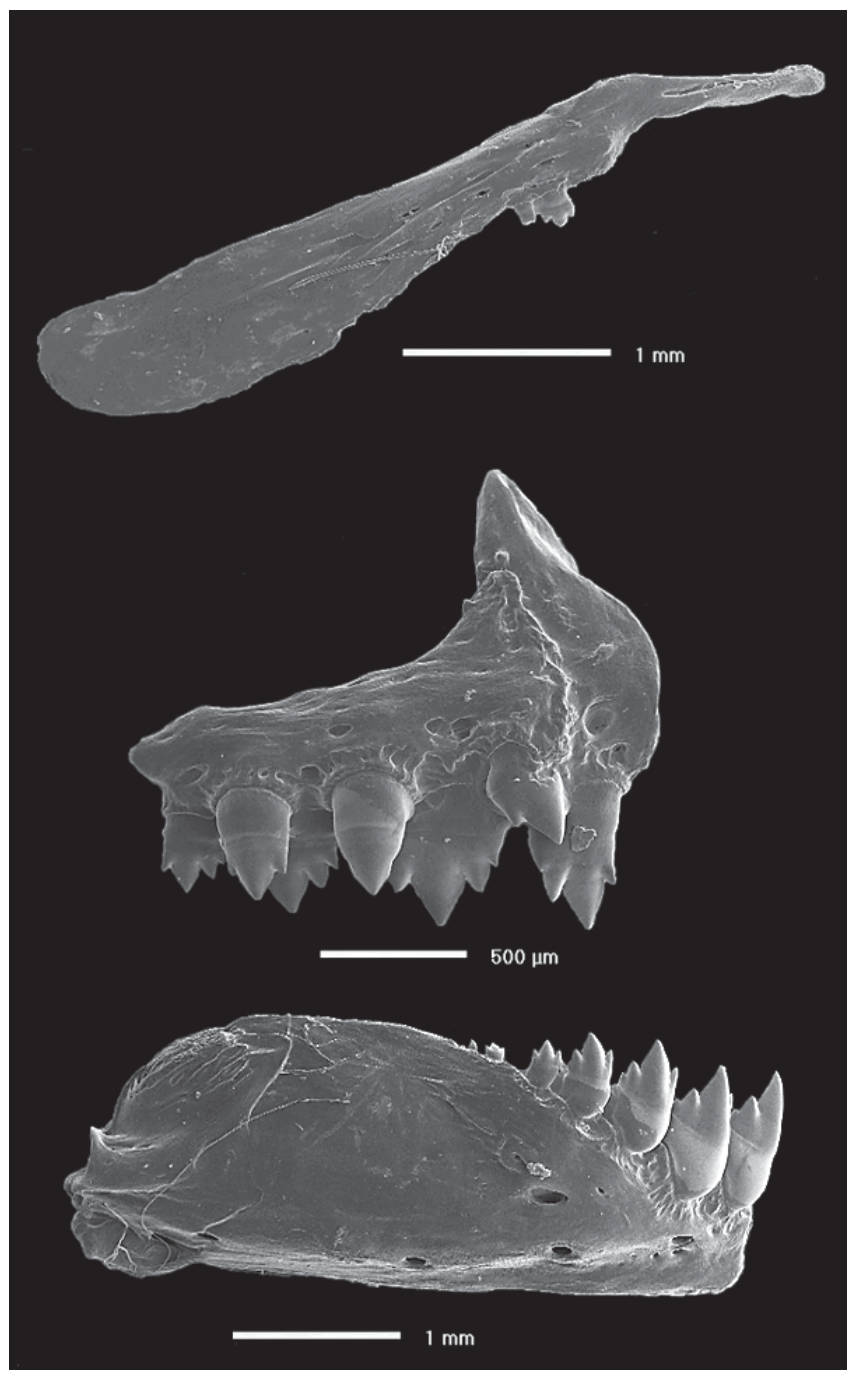

Fig. 2. Hyphessobrycon hamatus, MCP 33930, paratype, 38.3 mm SL. SEM photograph of right side maxillary (top), premaxillary (middle), and dentary (bottom) teeth.
Table 1. Morphometric data of holotype $(\mathrm{H})$ and paratypes of Hyphessobrycon hamatus from the upper rio Tocantins drainage $(\mathrm{n}=23$ including the holotype), and paratypes of Hyphessobrycon balbus; CAS 60463 (6 of 15).

\begin{tabular}{|c|c|c|c|c|c|}
\hline & \multicolumn{3}{|c|}{ H. hamatus } & \multicolumn{2}{|c|}{ H. balbus } \\
\hline & $\mathrm{H}$ & Range & Mean & Range & Mean \\
\hline \multirow[t]{2}{*}{ Standard length (mm) } & 43.1 & $29.0-44.8$ & 35.6 & $23.1-30.6$ & 27.9 \\
\hline & \multicolumn{5}{|c|}{ Percents of SL } \\
\hline Predorsal distance & 58.3 & $57.1-63.4$ & 59.8 & $59.7-62.0$ & 60.5 \\
\hline Prepelvic distance & 51.9 & $50.2-55.2$ & 52.7 & $52.3-54.6$ & 53.1 \\
\hline Prepectoral distance & 27.8 & $27.0-31.0$ & 29.0 & 28.3-30.8 & 29.5 \\
\hline Preanal distance & 69.1 & $67.1-71.3$ & 69.4 & $69.5-72.4$ & 70.9 \\
\hline Depth at dorsal-fin origin & 34.8 & $34.8-41.6$ & 37.4 & $40.6-45.6$ & 42.0 \\
\hline Caudal peduncle depth & 13.9 & $12.0-15.1$ & 13.5 & $12.4-13.0$ & 12.7 \\
\hline Caudal peduncle length & 14.4 & $10.0-14.4$ & 12.1 & $10.2-11.3$ & 10.8 \\
\hline Anal-fin base & 24.3 & $21.5-26.2$ & 24.2 & $24.6-27.5$ & 25.9 \\
\hline Dorsal-fin length & 25.9 & $24.3-29.4$ & 26.8 & $27.9-30.6$ & 29.5 \\
\hline Pelvic-fin length & 17.8 & 16.4-19.8 & 17.9 & $16.8-19.3$ & 13.3 \\
\hline Pectoral-fin length & 21.3 & $18.8-24.6$ & 22.2 & $21.1-22.4$ & 21.8 \\
\hline \multirow[t]{2}{*}{ Head length } & 28.6 & $27.5-32.3$ & 29.7 & $29.3-31.3$ & 30.2 \\
\hline & \multicolumn{5}{|c|}{ Percents of $\mathrm{HL}$} \\
\hline Snout length & 23.1 & $22.3-25.5$ & 23.6 & $20.7-23.0$ & 22.0 \\
\hline Upper jaw length & 43.7 & $40.2-46.8$ & 43.2 & $37.6-41.2$ & 39.4 \\
\hline Orbital diameter & 31.3 & 29.1-33.7 & 31.4 & $35.8-38.7$ & 37.3 \\
\hline Interorbital width & 38.6 & $33.4-41.0$ & 36.0 & $27.7-31.8$ & 29.5 \\
\hline
\end{tabular}

Caudal-fin forked, with 19 principal rays without bony hooks. Dorsal procurrent rays 11. Ventral procurrent rays 10.

Scales cycloid, moderately large. Lateral line incomplete, perforated scales $10-32(\bar{x}=25.6, \mathrm{n}=27)$. Longitudinal scale series including lateral-line scales 33-35 ( $\bar{x}=34.1, \mathrm{n}=28)$. Scale rows between dorsal-fin origin and lateral line 5-6 (usually $6, \bar{x}=5.9, \mathrm{n}=28$ ); scale rows between lateral line and pelvic-fin origin $4-5$ (usually $5, \bar{x}=4.7, \mathrm{n}=28$ ). Predorsal scales 11-13, usually 12 , arranged in regular series $(\bar{x}=12.1)$. Scales rows around caudal peduncle $14-15(\bar{x}=14.1)$. Scale sheath along anal-fin base with 5-7 scales in single series, extending posteriorly to base of fourth to sixth branched rays.

Precaudal vertebrae 16; caudal vertebrae 17; total vertebrae 33. Supraneurals 6. Gill-rakers 6-7/11 $(n=2)$.

Color in alcohol. Dorsal and dorsolateral portions of head and body dark brown. Infraorbital and opercular areas covered with scattered, dark chromatophores. Scales on lateral and ventral surface of body bordered with dark brown chromatophores. Anterior humeral spot very discrete, vertically-elongate, and narrowing ventrally, located over second to third lateral-line scales and extending over 5-6 horizontal series of scales including lateral line. Second humeral spot diffuse, located nearly above 7 th-8th lateral line scale and at anterior end of midlateral stripe, and extending usually over 2-3 horizontal series of scales above lateral line. Faint midlateral body stripe extending from second humeral spot to tip of median caudal-fin rays, becoming gradually wider and more intensely pigmented towards caudal peduncle. Midlateral body stripe slightly expanded dorsally and ventrally along caudal peduncle and caudal-fin base and forming small spot (Fig. 1).

Sexual dimorphism. Males of $H$. hamatus are easily recog- 
nized by the presence of bony hooks on the dorsal-, pectoral-, anal- and pelvic-fin rays.

Distribution. Hyphessobrycon hamatus is known only from two tributaries of the rio Vermelho, in the headwaters of the rio Tocantins basin, Mambaí, Goiás, Brazil.

Etymology. The specific epithet hamatus is from the Latin, meaning hooked, referring to the presence in males of hooks on all fins, except the caudal fin.

Ecological notes. All specimens of H. hamatus were caught in lentic stretches of shallow streams with sand and scattered stones on the bottom, and moderate amount of riparian vegetation. Species collected with H. hamatus were Ancistrus sp., Astyanax sp., Cetopsorhamdia sp., Characidium sp., Knodus sp., and Trichomycterus sp.

\section{Discussion}

The new species is described as a Hyphessobrycon in keeping with the current definition of the genus, proposed by Durbin in Eigenmann (1908) and further elaborated by Eigenmann (1918), and which is still in use (Reis et al., 2003): premaxillary teeth in two rows; maxillary teeth absent or reduced in number and restricted to the upper portion of its free margin; lateral line incomplete; adipose fin present, and caudal fin naked (not covered with scales).

As discussed by Weitzman \& Malabarba (1998) and Lucena (2003:93-94), there is no evidence that Hyphessobrycon is monophyletic and recognition of monophyletic groups among Hyphessobrycon species is complicated by the difficulty in finding characters useful for hypothesis of relationships among the species. Weitzman \& Palmer (1997) essentially attempted to define one group of Hyphessobrycon that they called the rosy tetras, but their paper well demonstrates the fuzzy boundaries of such a group. The question remains unanswered regarding what parts of the rosy tetras are historically real from a phylogenetic point of view and what parts are simply convergent. Weitzman \& Malabarba (1998) pointed out that large characid genera such as Hyphessobrycon in some of their sections often have minimal morphological divergence useful for cladistic analyses of their species. Much of the information used to distinguish species are probably labile features such as small variations in color patterns, scales, finray, tooth, and vertebral counts, that are, at least in part, uninformative about phylogenetic relationships. On the other hand the three new species of Hyphessobrycon described in a single paper by Lima \& Moreira (2003) represent some of the great external morphological diversity, found in the genus. However, that divergence does not render characters useful in the establishment of phylogenetic relationships, rather it suggests the phylogenetic unreliability of the traditional characters used to define Hyphesobrycon.

As discussed by Weitzman \& Malabarba (1998) and Lucena (2003:93-94), there is no evidence that Hyphessobrycon in monophyletic, and recognition of monophyletic groups among Hyphessobrycon species is complicated by the difficulty in finding characters useful for hypothesis of relationships among the species. Weitzman \& Malabarba (1998) pointed out that large characid genera such as Hyphessobrycon often have minimal morphological divergence useful for cladistic analyses of their species. Much of the information used to distinguish species are probably labile features such as small variations in color patterns, scales, fin-ray, tooth, and vertebral counts, that are, at least in part, uninformative about phylogenetic relationships. Curiously and apparently contrasting Weitzman \& Malabarba (1998), three new species of Hyphessobrycon described in a single paper by Lima \& Moreira (2003) present a great external morphological diversity, but that has not rendered characters useful in the establishment of phylogenetic relationships.

Hyphessobrycon hamatus possesses dark chromatophores delineating the scale borders over the body, a character uncommon among congeners but found in $H$. balbus Myers, $H$. langeanii Lima \& Moreira, and $H$. boulengeri (Eigenmann) (including $H$. reticulatus as a synonym; $c f$. Malabarba, 1989:134). Within the Tetragonopterinae sensu Géry (1977), such a pattern is also found in Moenkhausia oligolepis, M. sanctaefilomenae, M. pyrophthalma and $M$. diktyota (Lima \& Toledo-Piza, 2001). The lack of caudal-fin scales distinguishes H. hamatus from all these Moenkhausia species. The vertically-elongate humeral spot in H. hamatus easily distinguish this species from $H$. langeani that possesses an oval, horizontally-elongate humeral spot.

Hyphessobrycon hamatus, $H$. boulengeri and $H$. balbus share a reticulate scale pattern, a vertical humeral spot, and a caudal spot, but the bony hooks described for $H$. hamatus are unknown on the dorsal and pectoral fins of males in $H$. balbus and $H$. boulengeri. The number of the perforated scales in most Hyphessobrycon species usually varies between 4 to 16. Hyphessobrycon boulengeri has 5-7 pored lateral line scales, whereas $H$. hamatus and $H$. balbus possess a relatively high number of perforated scales $(10-32, \bar{x}=25.6, \mathrm{n}=$ 27, in a longitudinal series bearing 33-35 scales in H. hamatus; and 11-20 in a longitudinal series bearing 32-34 scales in $H$. balbus. See remarks on H. balbus below). Hyphessobrycon hamatus differs from $H$. balbus in the number of branched anal-fin rays (16-18) versus (17-20), the shallower depth at the dorsal-fin origin $(34.8-41.6 \%, \bar{x}=37.4, \mathrm{n}=23$, versus 40.6 $45.6 \%, \bar{x}=42.0, \mathrm{n}=6)$, smaller orbital diameter $(29.1-33.7 \%$, $\bar{x}=31.4, \mathrm{n}=23$, versus $35.8-38.7 \%, \bar{x}=37.3, \mathrm{n}=6$ ), and larger interorbital width $(33.4-41.0 \%, \bar{x}=36.0, \mathrm{n}=23$, versus 27.7 $31.8 \%, \bar{x}=29.5, \mathrm{n}=6$ ), respectively (Table 1 ).

Mature males of $H$. hamatus possess bony hooks in rays in all fins, except in the caudal fin. The presence of hooks on the anal- and pelvic-fin rays and sometime caudal-fin rays of males is often found in several genera and subfamilies of the Characidae (Azpelicueta \& Garcia, 2000; Malabarba \& Weitzman, 2003), and usually represent a secondary sexual character. The presence of bony hooks on the dorsal-fin rays is known to occur only in two Hyphessobrycon species: $H$. 
socolofi and H. erythrostigma (Weitzman, 1977). Hyphessobrycon hamatus can be easily distinguished from these species by a lower number of anal-fin rays (iii-v, 16-18, $\bar{x}=17, \mathrm{n}=28$ ) versus (iv, 28-30 and iv, 27-29, respectively), and by the absence of a black spot on the dorsal fin.

Seven Hyphessobrycon species were previously described from the rio Araguaia and rio Tocantins drainages: $H$. haraldschultzi Travassos, H. stegemanni Géry, H. amandae Géry \& Uj, H. moniliger Moreira, Lima \& Costa, H. eilyos, $H$. langeanii, and $H$. weitzmanorum Lima \& Moreira.

Remarks on Hyphessobrycon balbus. Myers (1927) noted the presence of some specimens with a complete lateral line in his description of $H$. balbus. We examined a series of paratypes of the species and all specimens have incomplete lateral line. Marilyn Weitzman found two of the 9 paratypes from CAS 118069 with a complete lateral line, but noticed that they are apparently a species of Astyanax and not $H$. balbus (S. H. Weitzman, pers. comun.).

The type locality of $H$. balbus (lagoa Fervedeira, Planaltina, Goiás, Brazil) has presented problems. Looking at the sequence of the localities of Ternetz collections recorded by N. E. Pearson as listed in an unpublished list of Ternetz localities for the years 1923-1925, it appears that lagoa Fervedeira lies near Planaltina. A Millionth Map (S. D-23 for Carinhanha), published in 1933, lists Planaltina as Alta Mira and shows a little nearby lake at the headwaters of the rio São Bartolomeu which ultimately flows into the rio Paraná. This little lake (now appearing on more recent maps as a swamp close to Planaltina) was then called lagoa Fervedeira (S. H. Weitzman, pers. comm.).

Comparative material. Hyphessobrycon balbus, CAS 60463 (15 paratypes, 15.4-31.6 mm SL), lagoa Fervedeira, Planaltina, Goiás, Brazil. Hyphessobrycon boulengeri, MCP 21685 (11, 26.0-33.2 mm SL), channel between lagoa Emboaba and Emboabinha, Osório, Rio Grande do Sul, Brazil.

\section{Acknowledgments}

We are grateful to S. H. Weitzman and M. Weitzman for comments on type-specimens and type-locality of $H$. balbus; to the Centro de Microscopia e Microanálises - CEMM, PUCRS for the SEM preparations; and David Catania (CAS) for selection and loan of specimens. José P. da Silva made the photograph. This paper benefited from comments and criticisms by Stanley Weitzman, Carlos Lucena, Flávio Lima and an anonymous reviewer. CNPq (Proc. 476821/2003-7; Proc. 464545/00-5).

\section{Literature cited}

Azpelicueta, M. M. \& J. O. Garcia. 2000. A new species of Astyanax (Characiformes, Characidae) from Uruguay river basin in Argentina, with remarks on hook presence in Characidae. Revue Suisse de Zoologie, 107(2):245-257.
Eigenmann, C. H. 1908. Zoological results of the Thayer Brazilian Expedition. Preliminary descriptions of new genera and species of Tetragonopterid characins. Bulletin of the Museum of Comparative Zoology, 52(6):93-106.

Eigenmann, C. H. 1918. The American Characidae. Part 2. Memoirs of Museum of Comparative Zoology, 43:103-208.

Eigenmann, C. H. 1921. The American Characidae. Part 3. Memoirs of Museum of Comparative Zoology, 43:209-310.

Fink, W. L. \& S. H. Weitzman. 1974. The so-called Cheirodontin fishes of Central America with descriptions of two new species (Pisces: Characidae). Smithsonian Contributions to Zoology, 172:1-46.

Géry, J. 1961. Three new South American characids, Knodus savannensis, Hyphessobrycon herbertaxelrodi and Megalamphodus sweglesi, with a review of some Hyphessobrycon-groups of species (Contr. No. 16). Tropical Fish Hobbyist, 9(9):26-46.

Géry, J. 1966. Hyphessobrycon vilmae sp. n., a new tetra from the upper Juruena, Brazil, with keys to the Heterorhabduslike species. Ichthyologica/The Aquarium Journal, 63-70.

Géry, J. 1977. Characoids of the World. THF Publications, Neptune City, NJ, 672 p.

Lima, F. C. T. \& M. Toledo-Piza . 2001. New species of Moenkhausia (Characiformes: Characidae) from the rio Negro of Brazil. Copeia, 2001 (4):1058-1063.

Lima, F. C. T., L. R. Malabarba, P. A. Buckup, J. F. Pezzi da Silva, R. P. Vari, A. Harold, R. Benine, O. T. Oyakawa, C. S. Pavanelli, N. A. Menezes, C. A. S. Lucena, M. C. S. L. Malabarba, Z. M. S. Lucena, R. E. Reis, F. Langeani, L. Casatti, V. A. Bertaco, C. Moreira \& P. H. F. Lucinda. 2003. Genera incertae sedis in Characidae. Pp. 134-141. In: R. E. Reis, S. O. Kullander \& C. J. Ferraris (Eds.). Check List of the Freshwater Fishes of South and Central America. Edipucrs, Porto Alegre, $729 \mathrm{p}$.

Lima, F. C. T. \& C. R. Moreira. 2003. Three new species of Hyphessobrycon (Characiformes: Characidae) from the upper rio Araguaia basin in Brazil. Neotropical Ichthyology, 1(1):21-33.

Lucena, C. A. S. 2003. New characid fish, Hyphessobrycon scutulatus, from the rio Teles Pires drainage, upper rio Tapajós system (Ostariophysi: Characiformes: Characidae). Neotropical Ichthyology, 1(2):93-96.

Malabarba, L. R. 1989. Histórico sistemático e lista comentada das espécies de peixes de água doce do sistema da laguna dos Patos, Rio Grande do Sul, Brasil. Comunicações do Museu de Ciências e Tecnologia da PUCRS, Sér. Zool., Porto Alegre, 2(8):107-179.

Malabarba, L. R. \& S. H. Weitzman. 2003. Description of new genus with six new species from southern Brazil, Uruguay and Argentina, with a discussion of a putative characid clade (Teleostei: Characiformes: Characidae). Comunicações do Museu de Ciências e Tecnologia da PUCRS, Sér. Zool., Porto Alegre, 16(1):67-151.

Myers, G. S. 1927. Descriptions of new South American freshwater fishes collected by Dr. Carl Ternetz. Bulletin of the Museum of Comparative Zoology, 68(3):109-133. 
Reis, R. E., S. O. Kullander \& C. J. Ferraris (eds.). 2003. Check List of the Freswater Fishes of South and Central America. Edipucrs, Porto Alegre, 729 p.

Taylor, W. R., \& G. C. Van Dyke. 1985. Revised procedures for staining and clearing small fishes and other vertebrates for bone and cartilage. Cybium, 9:107-119.

Weitzman, S. H. 1977. Hyphessobrycon socolofi, a new species of characoid fish (Teleostei: Characidae) from the Rio Negro of Brazil. Proceedings of the Biological Society of Washington, 90(2):326-347.

Weitzman, S. H. \& L. Palmer. 1997. A new species Hyphessobrycon (Teleostei: Characidae) from the Nebli- na region of Venezuela and Brazil, with comments on the putative 'rosy tetra clade'. Ichthyological Exploration of Freshwaters, 7(3):209-242.

Weitzman, S. H. \& L. R. Malabarba. 1998. Perspectives about the phylogeny and classification of the Characidae (Teleostei: Characiformes). Pp. 161-170. In: L. R. Malabarba, R. E. Reis, R. P. Vari, Z. M. S. Lucena, and C. A. S. Lucena (Eds.). Phylogeny and Classification of Neotropical Fishes. Edipucrs, Porto Alegre, 603p.

Received August 2004

Acepted January 2005 